\title{
Effect of Freezing and Frozen Storage on the Properties of Actomyosin from Pinkperch (Nemipterus japonicus)
}

\author{
K. Rathnakumar ${ }^{1 *}$ and B. A. Shamasundar ${ }^{2}$ \\ ${ }^{1}$ Department of Fish Process Engineering, College of Fisheries Engineering, Tamil Nadu \\ Fisheries University, Nagapattinam-611001 India \\ ${ }^{2}$ Department of Fish Processing Technology, College of Fisheries UAS, \\ Mangalore - 575 002, India \\ *Corresponding author
}

\section{A B S T R A C T}

\begin{tabular}{|l|}
\hline K e y w o r d s \\
Actomyosin, Pink perch, \\
$\begin{array}{l}\text { SDS - PAGE, dynamic } \\
\text { visco - elastic behaviour, } \\
\text { setting, Ca }{ }^{++} \text {ATPase }\end{array}$ \\
\hline Article Info \\
\hline $\begin{array}{l}\text { Accepted: } \\
22 \text { May } 2018 \\
\text { Available Online: } \\
\text { 10 June } 2018\end{array}$ \\
\hline
\end{tabular}

\section{Introduction}

Fish protein represent most important class of functional ingredient because they possess range of dynamic functional properties like organoleptic, hydration, surface and rheological/textural properties. Surimi, fish flesh, waterwashed mixed with cryoprotectants and frozen is highly functional in its character to produce visco-elastic gel via protein interaction, bind water and to form cohesive and strong membrane on the surface of the fat globules in emulsion system (Xiong 1997). In fish protein it is myosin and actomyosin complex which play a dominant

\begin{abstract}
Actomyosin from fresh pinkperch (Nemipterus japonicus) meat was isolated and its properties were assessed. The SDS-PAGE pattern indicated multiple bands in the molecular weight range of $2 \times 10^{5} \mathrm{KD}$ to $2 \times 10^{4} \mathrm{KD}$. The dynamic viscoelastic behaviour revealed sol-gel transition at 2 temperatures, $36.7^{\circ} \mathrm{C}$ and $63.3^{\circ} \mathrm{C}$. Setting of actomyosin at $30^{\circ} \mathrm{C}$ for $1 \mathrm{hr}$ could increase the storage modulus values significantly. The freezing and frozen storage of actomyosin alter solubility in high ionic strength buffer by $17.9 \%$ and duction in $\mathrm{Ca}^{++}$ATPase activity by $41.8 \%$. The apparent reduced viscosity as a function of protein concentration of actomyosin indicated a possible aggregation process. A reduction in myosin heavy chain concentration with storage period was revealed by SDSPAGE pattern. A progressive reduction in storage modulus values were observed with increase in frozen storage period. This pattern were also observed in set actomyosin.
\end{abstract}

role in imparting various functional properties contributing to palatability or sensory perception of processed fish minced base products (Kinsella et al., 1994).

The functional and rheological properties of actomyosin from fish are subjected to change during processing (Lanier et al., 1982; Chalmers et al., 1992; Sano et al., 1994). The structural changes in the natural actomyosin complex during frozen storage will alter the functional properties leading to change in eating quality. Freeze denaturation of actomyosin is highly affected by storage temperatures (Fukuda 1986; Jiang 1977; 
Matsumoto 1980). The stability of actomyosin from cod, halibat, plaice and rose fish stored at $-12^{\circ} \mathrm{C},-18^{\circ} \mathrm{C}$ and $-23^{\circ} \mathrm{C}$ was correlated with the storage temperature and $-23^{\circ} \mathrm{C}$ was found to be the best (Dyer and Morton 1956).

When actomyosin is ground with salt it forms a sol and upon heating it turns to elastic gel (Noguchi 1986). The elasticity of the products prepared from surimi comes mainly from the thermal gelation characteristics of actomyosin (Sano et al., 1988). The sol gel transformation upon heating of muscle protein have been reported by many workers (Ishioroshi et al., 1979; Samejima et al., 1981; Lanier et al., 1982; Wu et al., 1985a). Both sol and gel have been considered as viscoelastic bodies. The response of the viscoelastic body when the stress is applied results in elastic deformation and viscous flow.

Thus the thermal gelation of actomyosin from fish species can be understood by determining the changes in both the elastic and viscous element during sol-gel transition. Changes in rigidity and viscosity during thermal gelation of actomyosin from croaker, dynamic viscoelastic behaviour of actomyosin from carp and dynamic rheological behaviour of actomyosin from rabbit have been reported (Wu et al., 1985b; Sano et al., 1988; Ikeuchi et al., 1994).

The frozen storage behaviour of actomyosin is highly species specific apart from storage temperature. A fundamental knowledge on the changes in the functional and rheologial properties especially gelling behaviour as affected by freezing and frozen storage will help in evolving a corrective measures.

In the previous paper (Rathnakumar and Shamasundar 2005a) changes in the properties of total proteins from pinkperch meat during freezing and frozen storage has been reported. In the present paper actomyosin has been isolated and the effect of freezing and frozen storage at $-20^{\circ} \mathrm{C}$ on the physico-chemical, functional and rheological properties have been studied.

\section{Materials and Methods}

Fresh pink perch (Nemipterus japonicus) caught off Mangalore, west coast of India were procured on board and iced immediately in 1:1 ratio and packed in insulated container. The fishes were brought to the laboratory within $10 \mathrm{hrs}$ and used for actomyosin isolation immediately.

\section{Isolation of Actomyosin}

Natural actomyosin was isolated according to the method described by Kawashima et al., (1973) from $100 \mathrm{~g}$ of mince. Actomyosin pellets thus obtained were distributed into plastic vials (5 $\mathrm{g}$ each) and subjected to air blast freezing at $-35^{\circ} \mathrm{C}$ for $45 \mathrm{~min}$. and stored in deep freezer at $-20^{\circ} \pm 1^{\circ} \mathrm{C}$.

The frozen actomyosin samples were drawn periodically and various functional and rheological properties were assessed.

Proximate composition, Nitrogen solubility index (NSI), nitrogen solubility as a function of sodium chloride concentration, solubility of actomyosin in extraction buffer, viscosity, $\mathrm{Ca}^{2+}$ ATPase activity, SDS-PAGE pattern, emulsion capacity (EC), emulsion stability (ES) water absorption capacity (WAC) and were determined according to the method described in the previous paper (Rathnakumar and Shamasundar 2005a).

Dynamic viscoelastic behaviour of actomyosin was carried out by using Controlled Stress Rheometer under oscillation mode. The experimental details have been described in the previous paper (Rathnakumar and Shamasundar 2005a). 


\section{Gel filtration}

Gel filtration of soluble actomyosin was performed using sepharose $6 \mathrm{~B}$ gel packed in a column of $0.5 \times 60 \mathrm{~cm}$ at the flow rate of $25-30$ $\mathrm{ml} / \mathrm{hr}$. The bed volume $\left(\mathrm{v}_{\mathrm{t}}\right)$ of the column was $50 \mathrm{ml}$ and the void volume $\left(\mathrm{v}_{\mathrm{o}}\right)$ was $12 \mathrm{ml}$. The void volume was determined using blue dextran. A known concentration of protein (4$5 \mathrm{mg}$ ) was loaded to column and eluted with extraction buffer (EB). Fractions of 3.0-3.5 ml were collected manually and measured at 280 $\mathrm{nm}$ using Bausch and Lomb spectronic -21, spectrophotometer. A plot of absorbance versus elution volume was obtained.

\section{Results and Discussion}

The composition and properties of actomyosin (AM) from fresh pink perch are given in Table 1. Bulk of the actomyosin accounted for moisture and protein constituted about 3 percent. The NPN content of actomyosin was $22.63 \mathrm{mg} / 100 \mathrm{~g}$ which was negligible in comparison to NPN content of meat (694 mg/100g - Rathna Kumar and Shamasundar 2005a). The protein solubility of fresh actomyosin in EB was $94.11 \%$. The solubility of fish protein in high ionic strength buffer is taken as index of denaturation by many workers (Dyer, 1951; Connell 1959; Shamasundar and Prakash, 1994a).

Further, the $\mathrm{Ca}^{2+}$ ATPase enzyme activity of fresh actomyosin $\quad(0.474 \quad \mu \mathrm{g} \quad \mathrm{Pi} / \mathrm{mg}$ protein/min) indicate the native state of the molecule. The Nitrogen solubility index of actomyosin is given in Fig. 1A. The minimum solubility occurred at the range of $\mathrm{pH} 5.75$ 6.5. Solubility increased both on acidic and alkaline $\mathrm{pH}$. These results showed that shifting of $\mathrm{pH}$ away from iso-electric point could solubilize more of actomyosin. Similar results reported by Kinsella (1982) Lin and park (1998). Solubility of actomyosin as a function of molar concentration of $\mathrm{NaCl}$ indicated salting 'in' phenomenon upto $1.0 \mathrm{M}$ concentration and salting 'out' at 1.5 and 2.0 $\mathrm{M}$ concentration. (Fig. 1B). Higher concentration of $\mathrm{NaCl} / \mathrm{KCl}$ are known to alter the solubility behaviour of myosin and actomyosin because of its interaction with water surrounding protein molecules. The solubility of myosin from salmon in $\mathrm{KCl}$ increased upto $1 \mathrm{M}$ and then decreased at 2 and $3 \mathrm{M}$, however the salting out process was much slower (Lin and park 1998). Hence, for protein solubility studies as a function of frozen storage, $1 \mathrm{M} \mathrm{NaCl}$ concentration in phosphate buffer (0.05 M, pH 7.5) was used as solvent.

The gel filtration profile of actomyosin on sepharose - 6B gel shows a single peak (Fig $4 \mathrm{~A})$ eluting at an volume of $32.6 \mathrm{ml}$. This single peak demonstrates a single component in the system. The SDS PAGE pattern of fresh actomyosin showed multiple bands (Fig.10 lane a) with molecular weight in the range of 2 $\times 10^{5} \mathrm{KD}$ to $2 \times 10^{4}$. The SDS-PAGE pattern indicates about 8 bands, 4 major and 4 minor bands. The concentration of myosin heavy chain (MHC) was high as evidenced by the intensity and breadth of the band.

The dynamic visco-elastic behaviour (DVB) of fresh actomyosin in the temperature range of $30^{\circ}-90^{\circ} \mathrm{C}$ is given in Fig. $6 \mathrm{~A}$. The storage modulus value $\left(G^{\prime}\right)$ indicative of elastic component increased with increase in temperature upto $83.3^{\circ} \mathrm{C}$. The rate of increase of $\mathrm{G}^{\prime}$ value was maximum in the temperature range of $36.7-43.7^{\circ} \mathrm{C}$ (Table 3). The loss modulus (G") values which is indicative of viscous element during gelation process showed an increasing trend upto $83.3^{\circ} \mathrm{C}$ and decreased to $140.9 \times 10^{3}$ dynes $/ \mathrm{cm}^{2}$ at $90^{\circ} \mathrm{C}$. The increase in G" values as a function of temperature sweep is much less compared to G' values which clearly suggests that actomyosin had ability to build up elastic component during heat processing. The 
structure build up reaction which is indicative of elastic component is maximum between $36.7^{\circ} \mathrm{C}$ and $43.6^{\circ} \mathrm{C}$. The sol-gel transition as indicated by $\tan \delta$ value occurred at two temperature viz., 36.7 and $63.3^{\circ} \mathrm{C}$. Using Thermal Scanning Rigidity Monitor (TSRM) Wu et al., (1985b) observed a (Transition) peak at $38^{\circ} \mathrm{C}$ in Atlantic Croaker actomyosin solution with increase in viscosity and attributed to high temperature 'setting' phenmenon. DSC studies also confirmed a transition at $36-38^{\circ} \mathrm{C}$ for the above species (Wu et al., 1985a). Surimi of Alaska pollock showed elastic structure build up at $45^{\circ} \mathrm{C}$ when heating rate was $1{ }^{\circ} \mathrm{C} / \mathrm{min}$ (Hamann 1992).

The freezing and frozen storage of actomyosin altered the $\mathrm{Ca}^{2+}$ ATPase enzyme activity and protein solubility significantly $(\mathrm{p}<0.05)$. The effect of freezing per se was dominant on ATPase enzyme activity as a reduction of $34 \%$ was recorded (Fig. 2). After 30 days of frozen storage there was an increase in ATPase activity to $0.472 \mu \mathrm{g} \mathrm{Pi} / \mathrm{mg}$ protein $/ \mathrm{min}$. This increase in ATPase enzyme activity was similar to that observed in total protein extract from pinkperch meat (Rathnakumar and Shamasundar 2004a). The percent protein extracted from actomyosin during different periods of frozen storage (Fig. 2) revealed a gradual decrease reaching a value of $20 \%$ at the end of 150 days. This decrease in solubility in the solvent used (EB) is mainly due to aggregation/ denaturation process brought about during frozen storage. This insolubilization of protein is mainly due to formation of larger aggregates by actomyosin complex (Shenouda, 1980; Wagner and Anon 1986) caused by the formation of disulfide bonds, and hydrophobic interactions (Jiang et al., $1988 \mathrm{a}, \mathrm{b})$.

The apparent reduced viscosity of actomyosin solution as a function of protein concentration at different periods of frozen storage is representated in the Fig.3A. The slope of the curve altered with increase in storage time indicating change in shape of the molecule. This change could be due to aggregation process of actomyosin molecule during storage as indicated by solubility and ATPase profile.

A derivative graph obtained (Fig. 3B) revealed that the apparent reduced viscosity at a protein concentration of $5 \mathrm{mg} / \mathrm{ml}$ decreased significantly $(\mathrm{p}<0.05)$ with storage period. Similar reduction during frozen storage of actomyosin from frozen hake (Montecchia et al., 1997) and carp (Noguchi and Matsumoto, 1978) were reported.

The changes in gel filtration (GF) profile of actomyosin is depicted in Fig 4A-G. From the figure an initial aggregation at the end of 30 days of frozen storage was evident as there was a shift in the elution volume from $32.6 \mathrm{ml}$ to $30.0 \mathrm{ml}$. With further increase in frozen storage period a dissociation process was observed with the shift in elution volume to $36.5,37.5,40.0$ and $40.8 \mathrm{ml}$ at the end of 50, 90,120 and 150 days of storage respectively.

The concentration of the actomyosin peak in the GF profile decreased with increase in storage period. This reduction in concentration is mainly due to decreased solubility of actomyosin in the solvent (EB) used and/or due to aggregation/denaturation. However, the gel filtration pattern clearly demonstrate aggregation - dissociation reaction.

The SDS-PAGE pattern of actomyosin as a function of frozen storage is represented in Fig.10. A reduction in MHC concentration was observed from the SDS-PAGE pattern. This suggests that the aggregates formed during storage is insolubilized even in cationic detergent like SDS. Such reports are common in literature for many fish and shell fish species (An et al., 1988, 1989, Tejada 1996). 
Fig.1 A: Nitrogen Solubility Index of total proteins from fresh actomyosin with distilled water as solvent B: Protein Solubility of fresh actomyosin as a function of molar concentration of sodium chloride in phosphate buffer $(50 \mathrm{mM}$; pH 7.5)
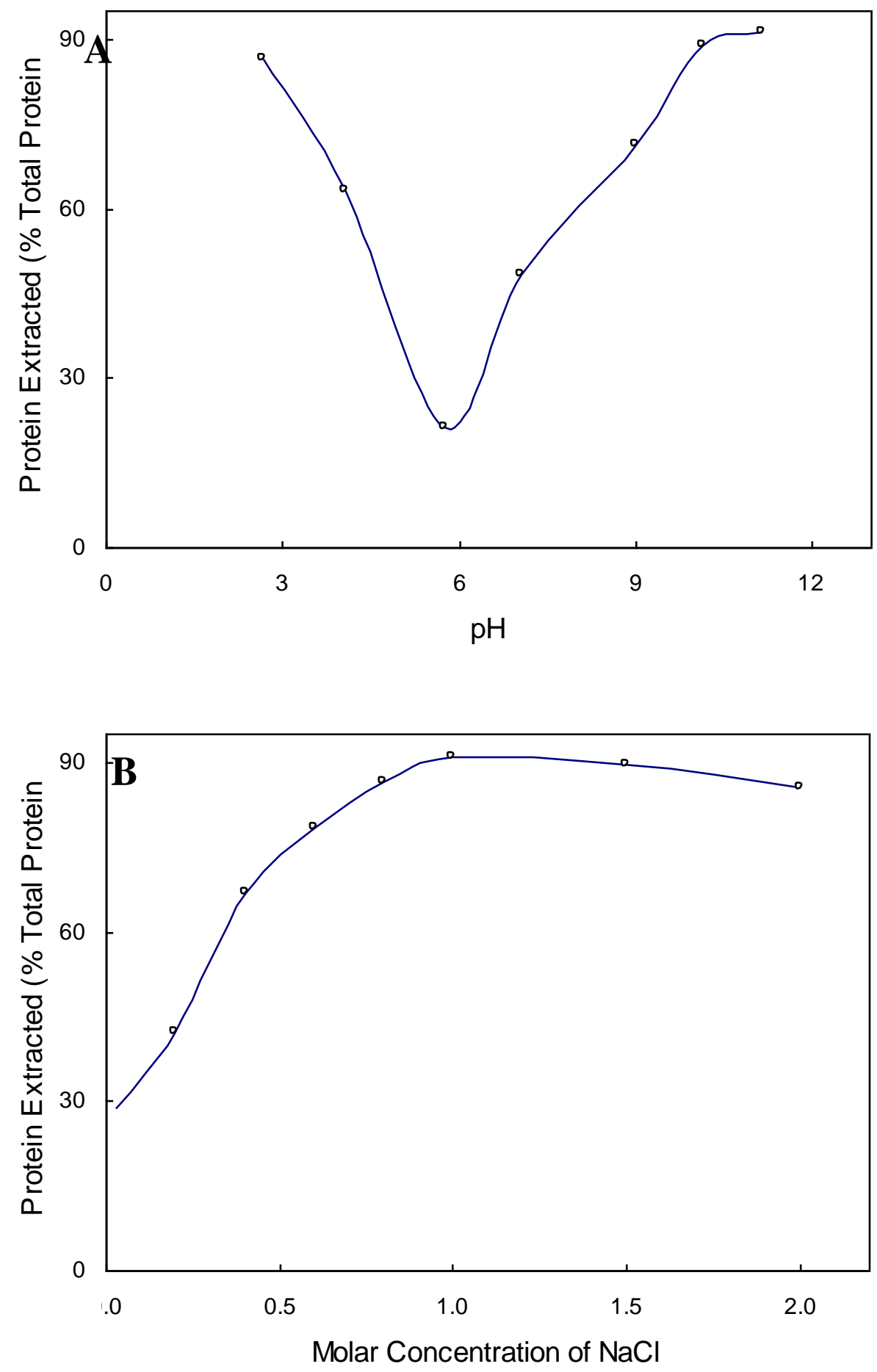
Fig.2 A: Effect of freezing and frozen storage at $-20^{\circ} \mathrm{C}$, of actomyosin on calcium ATPase activit! scle extract in Tris- $\mathrm{HCl}$ buffer, $\mathrm{pH} 8.0,50 \mathrm{mM}$. B: Effect of freezing and frozen storage at $-20^{\circ} \mathrm{C}$, of actomyosin on the solubility of total proteins. The solvent used was EB and soluble protein was expressed as \% solubilized of total protein content of meat
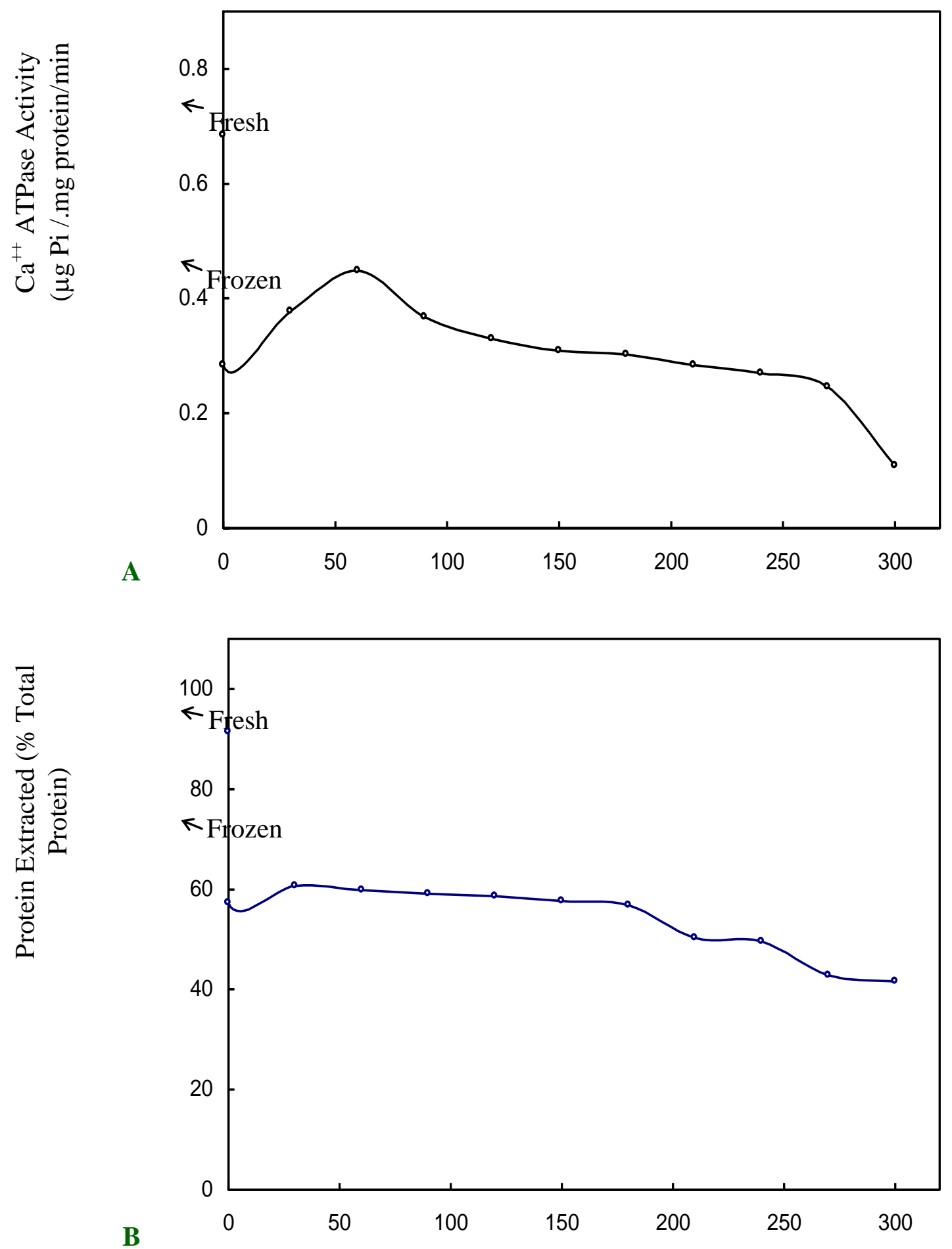
Fig.3 A: A derivative graph of apparent reduced viscosity of actomyosin at $5 \mathrm{mg} / \mathrm{ml}$ protein concentration as a function of freezing and frozen storage. B: Apparent reduced viscosity of actomyosin extracted in $\mathrm{EB}$, as a function of freezing and frozen storage at $-20^{\circ} \mathrm{C}$

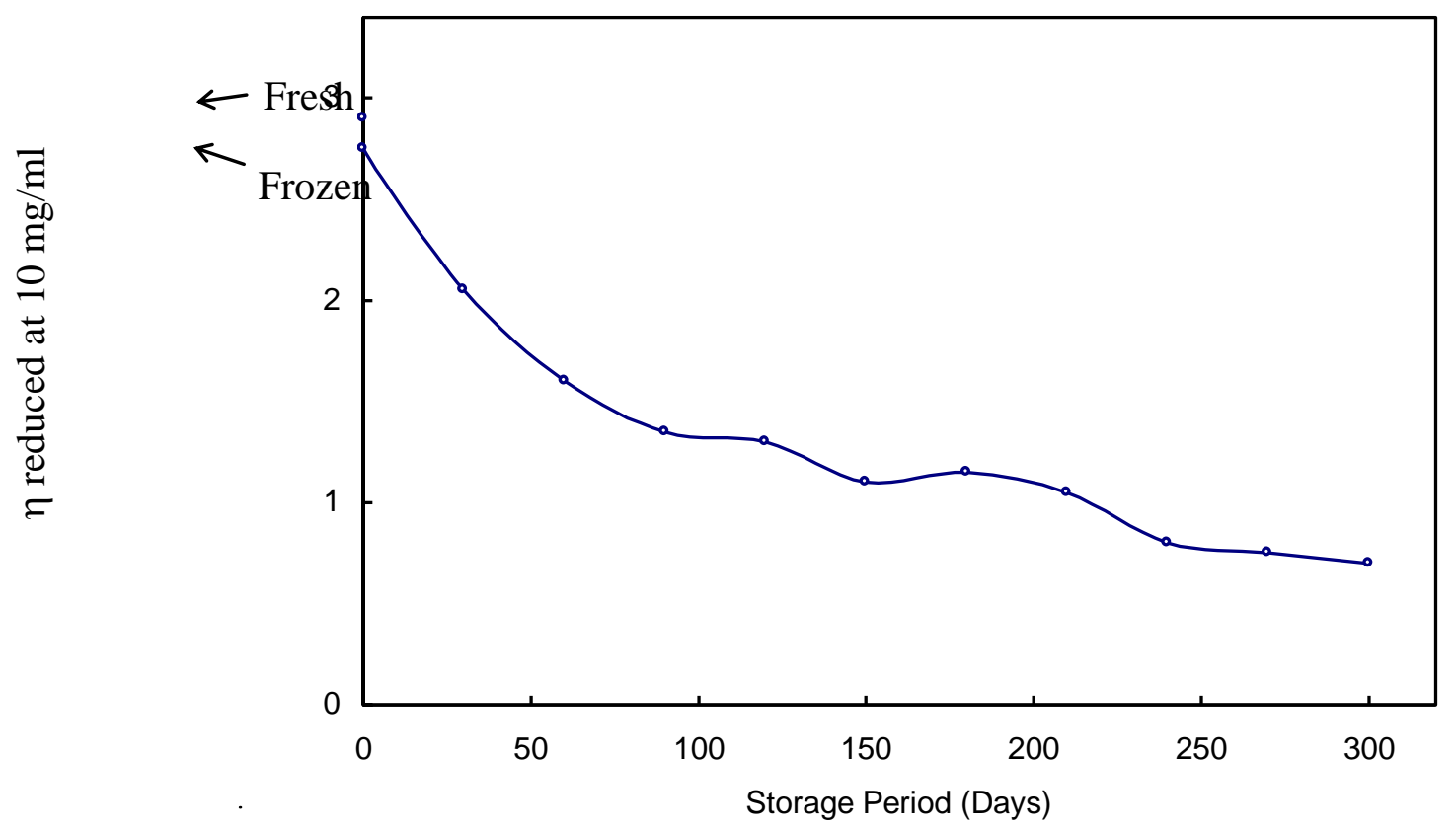

A

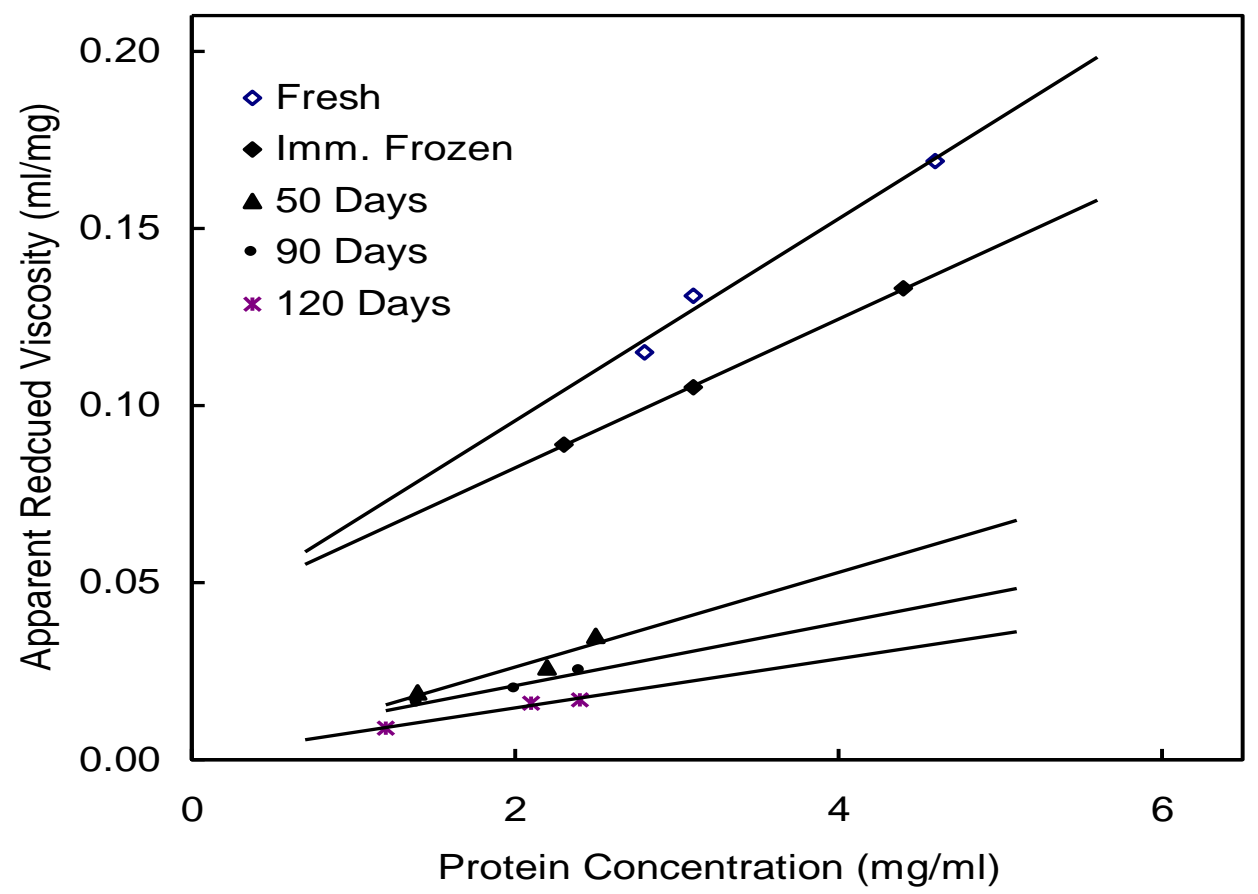

B. 
Fig.4 Changes in gel filtration profile of total protein from actomyosin on sepharose $6 \mathrm{~B}$ gel, as a function of freezing and frozen storage at $-20^{\circ} \mathrm{C}$. The eluant used was extraction buffer (phosphate buffer, $50 \mathrm{mM}$, pH 7.5; containing $1 \mathrm{M} \mathrm{NaCl}$ )

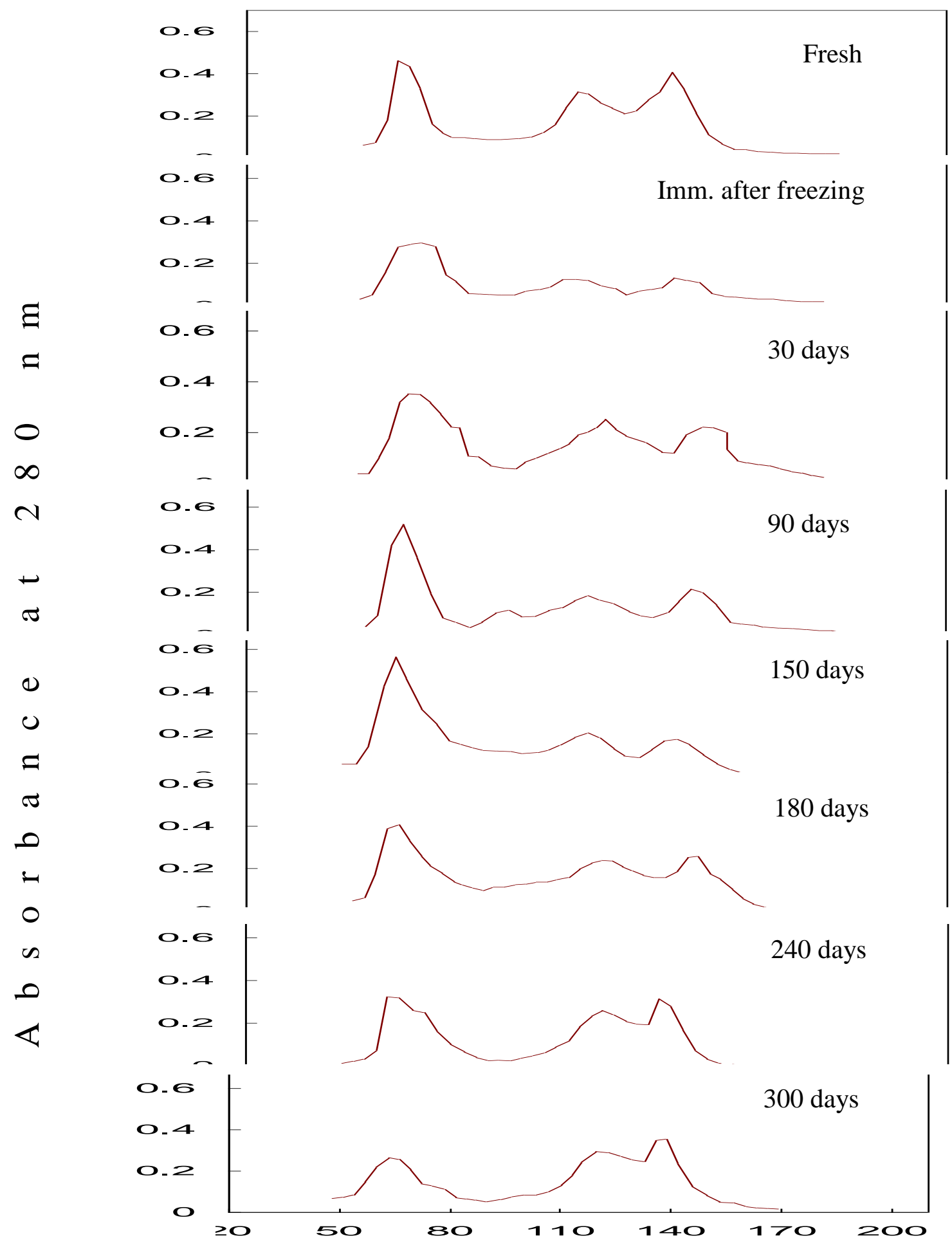

E l u t i o n V o l u m e (ml) 
Fig.5 Changes in EC\&ES of total proteins from actomyosin as a function of freezing and frozen storage at $-20^{\circ} \mathrm{C}$

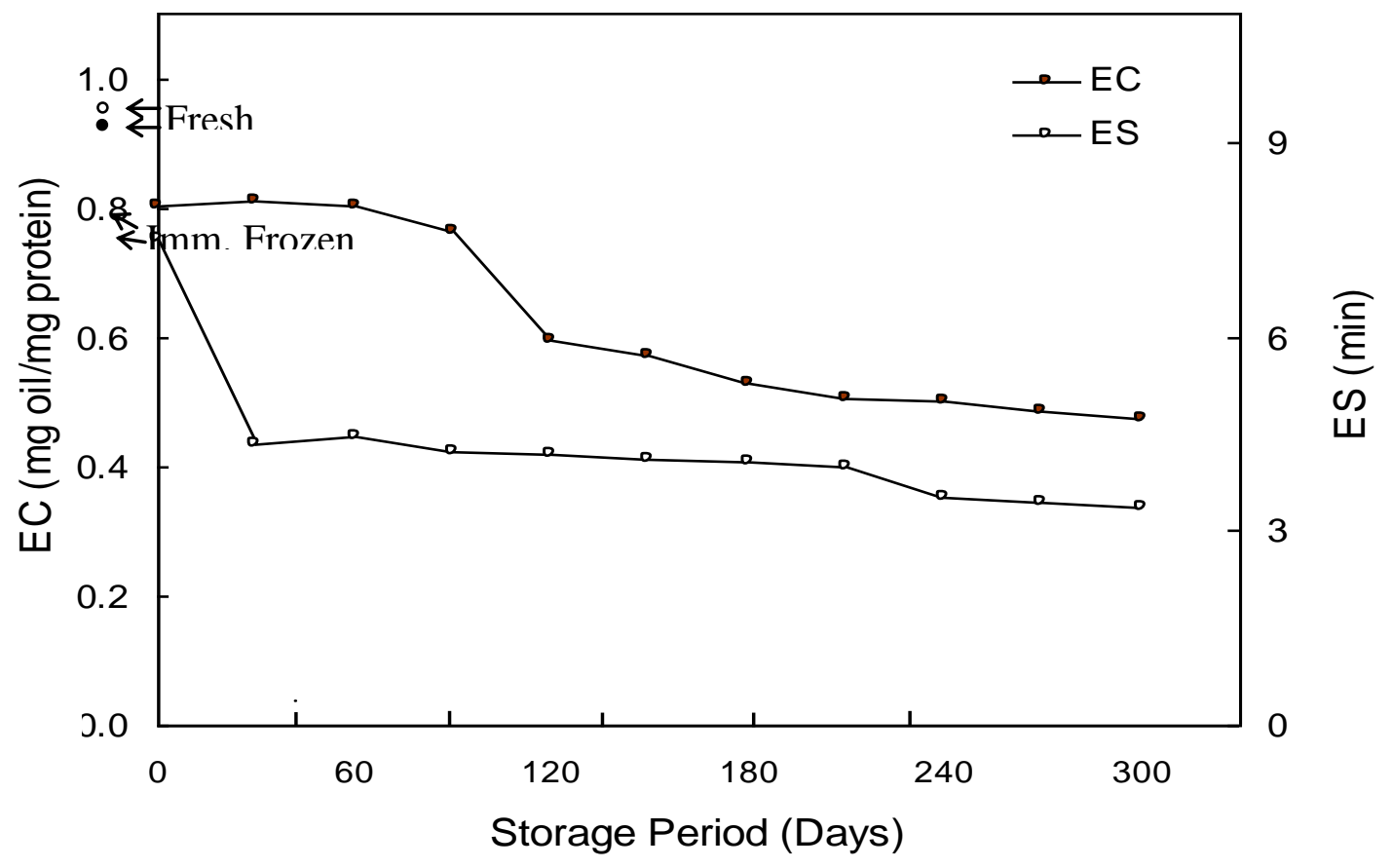

Fig.6 Changes in gel strength of set and unset meat of actomyosin as a function of freezing and frozen storage at $-20^{\circ} \mathrm{C}$

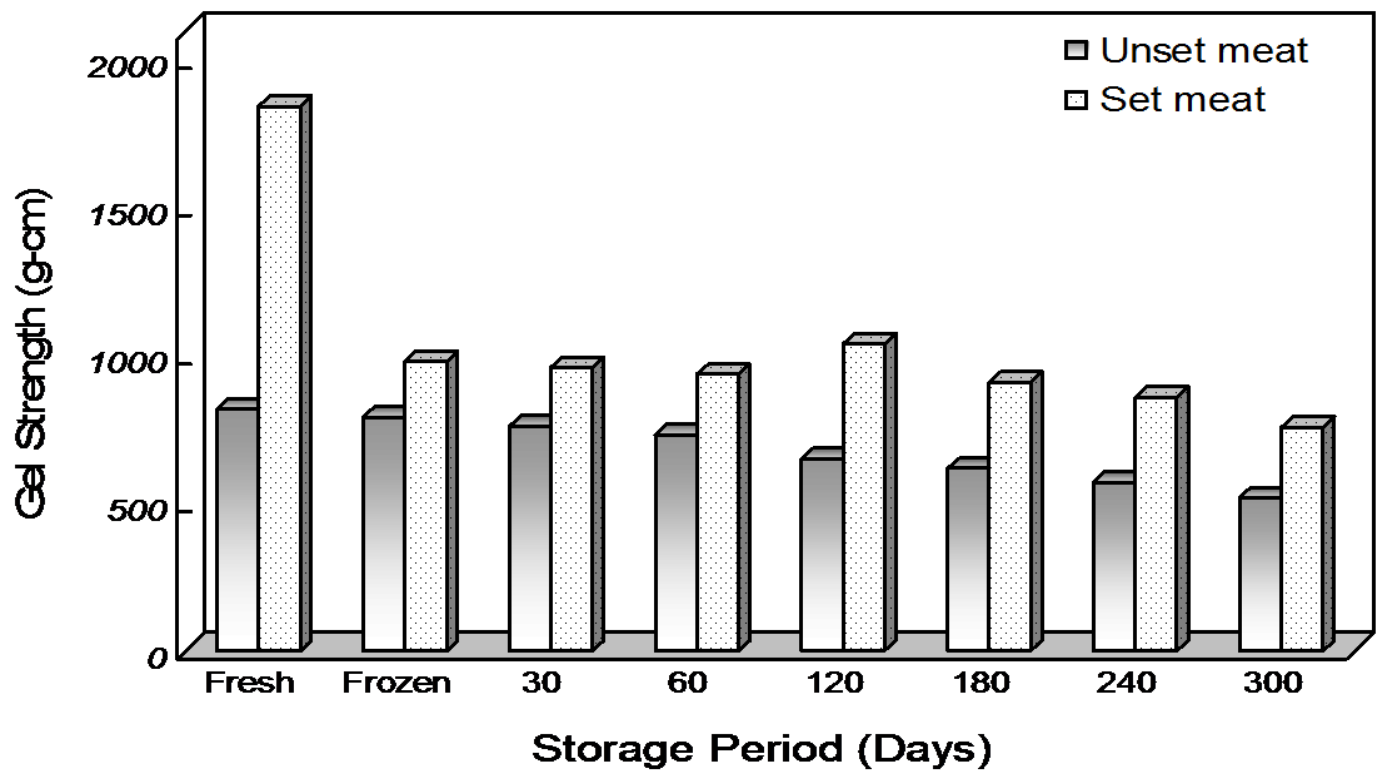


Fig.7 Changes in dynamic viscoelastic behaviour of actomyosin in the temperature range of 30$90^{\circ} \mathrm{C}$, as affected by freezing and frozen storage at $-20^{\circ} \mathrm{C}$. DVB was carried out under oscillatory mode

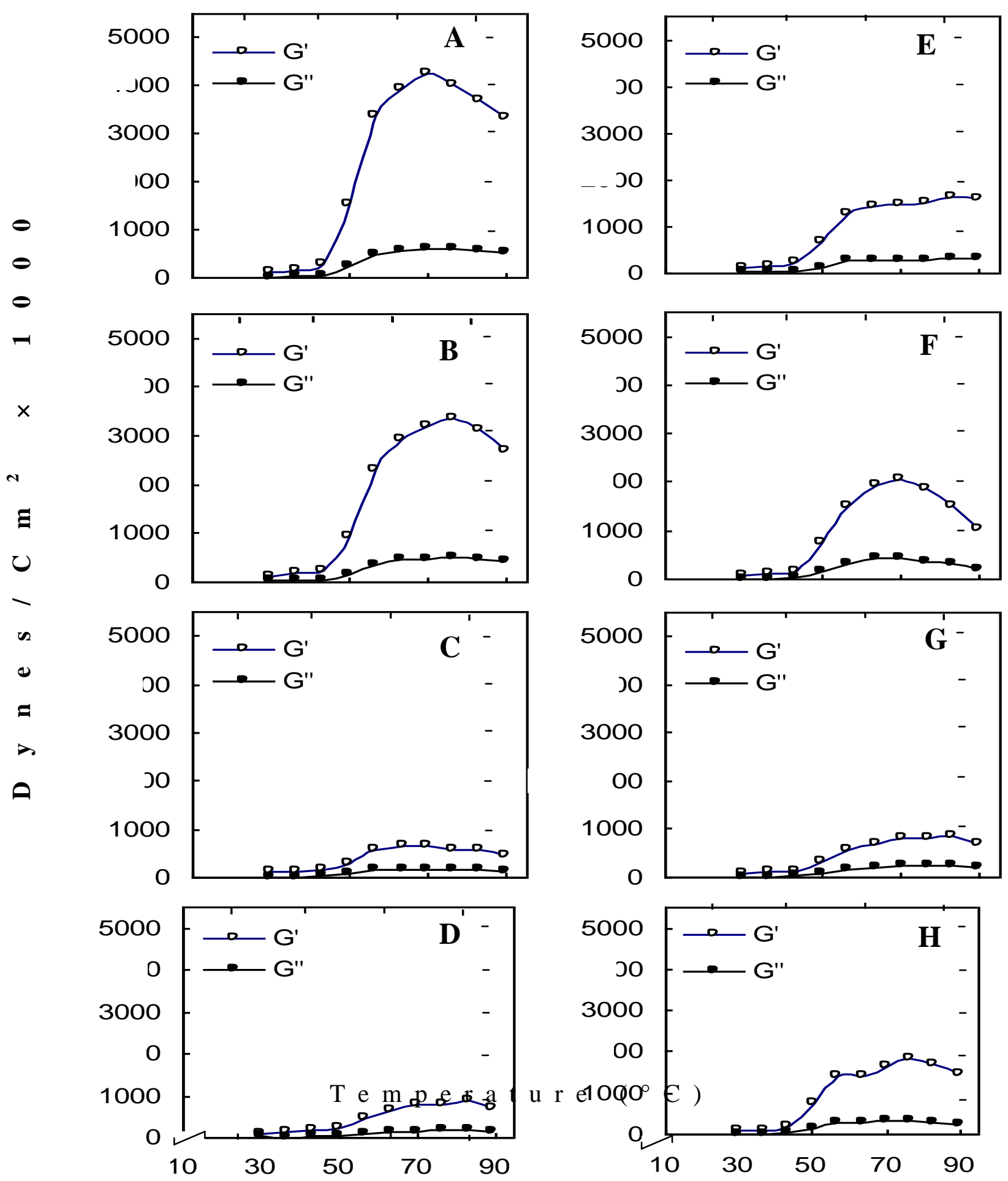

A) fresh actomyosin B) immediately after freezing C) 30 days D) 90 days E) 120 days F) 150 days G) 240 days $\mathrm{H}) 300$ days 
Fig.8 Changes in the dynamic viscoelastic behaviour of set actomyosin, in the temperature range of $30-90^{\circ} \mathrm{C}$ as a function of freezing and frozen storage at $-20^{\circ} \mathrm{C}$. The meat set at

$30^{\circ} \mathrm{C}$ for $1 \mathrm{hr}$

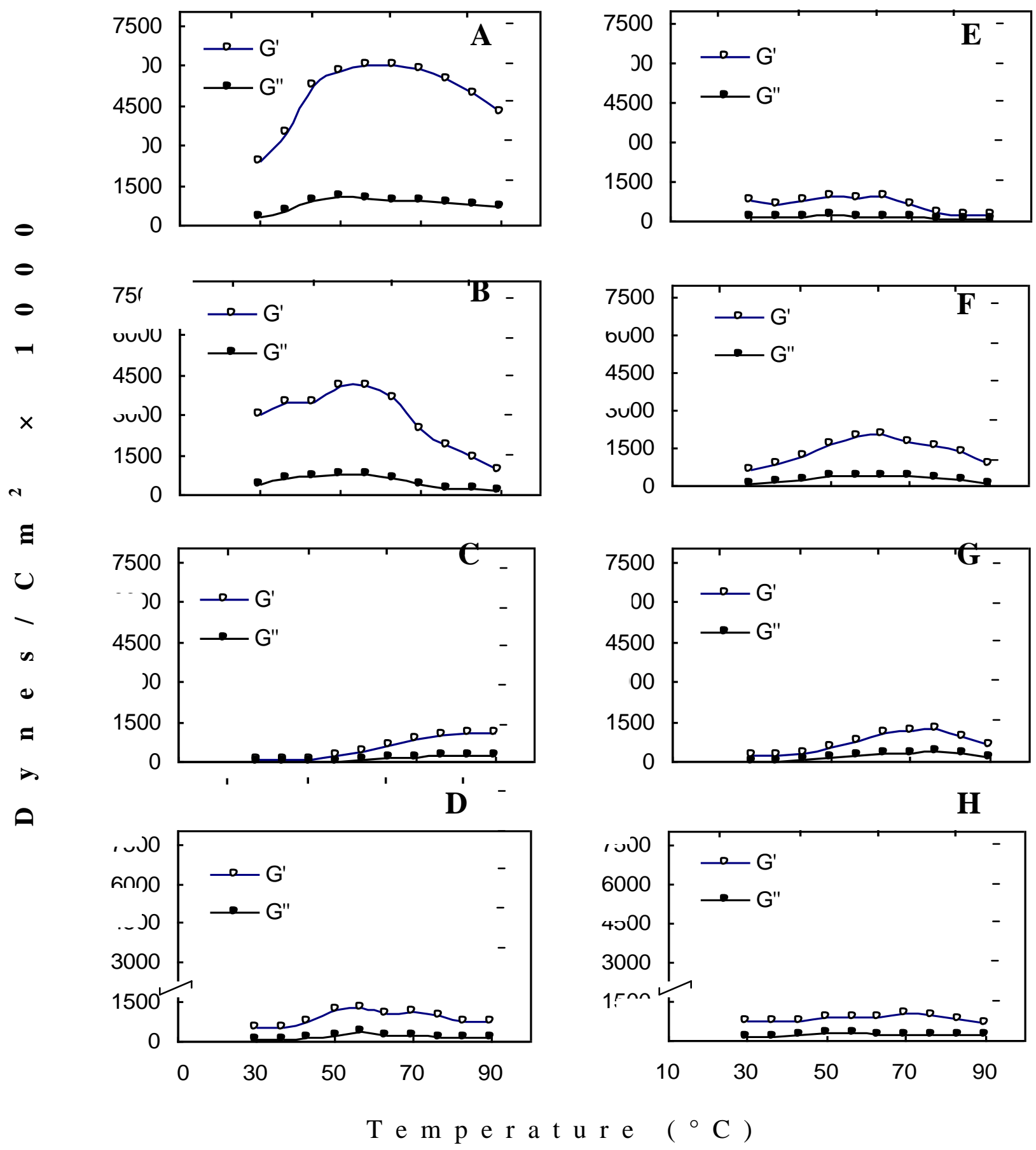

A) fresh actomyosin B) immediately after freezing days

H) 300 days

C) 30 days D) 90 days

E) 120 days F) 210 days

G) 240 
Table.1 Proximate composition and properties of actomyosin from pinkperch

\begin{tabular}{|l|l|}
\hline Moisture \% & $96.66( \pm 0.32)$ \\
\hline Protein \% & $3.054( \pm 0.22)$ \\
\hline Fat $\%$ & $0.280( \pm 0.12)$ \\
\hline Ash \% & $0.046( \pm 0.01)$ \\
\hline $\mathrm{NPN}(\mathrm{mg} / 100 \mathrm{~g}$ of actomyosin) & $22.63( \pm 0.052)$ \\
\hline $\mathrm{Ca}^{++} \mathrm{ATPase}$ activity in $(\mu \mathrm{g}$ Pi/mg protein/min) & $0.474( \pm 0.002)$ \\
\hline Emulsion capacity $(\mathrm{ml}$ oil/mg protein) & $3.741( \pm 0.72)$ \\
\hline Emulsion stability $(\mathrm{min})$ & $18.0( \pm 1.02)$ \\
\hline Water absorption capacity $(\mathrm{g}$ water/ g dried material) & $3.48( \pm 0.036)$ \\
\hline Extractability in EB $(\%$ total protein) & $94.11( \pm 0.46)$ \\
\hline $\begin{array}{l}\text { Reduced viscosity at zero protein concentration } \\
(\mathrm{ml} / \mathrm{mg})\end{array}$ & $0.045( \pm 0.02)$ \\
\hline
\end{tabular}

* Values in parenthesis indicate standard deviation, $\mathrm{n}=3$.

Table.2 Changes in water absorption capacity of AM as an effect of freezing and frozen storage at $-20^{\circ} \mathrm{C}$

\begin{tabular}{|l|l|}
\hline Storage period (days) & $\begin{array}{l}\text { Water absorption capacity }(\mathrm{g} \text { water/g dried } \\
\text { material })\end{array}$ \\
\hline Fresh & $3.48( \pm 0.036)$ \\
\hline Immediately frozen & $3.17( \pm 0.025)$ \\
\hline 30 & $3.34( \pm 0.045)$ \\
\hline 60 & $3.30( \pm 0.035)$ \\
\hline 90 & $3.20( \pm 0.025)$ \\
\hline 120 & $3.05( \pm 0.06)$ \\
\hline 150 & $3.0( \pm 0.05)$ \\
\hline
\end{tabular}

* Values in parenthesis indicate standard deviation, $\mathrm{n}=3$.

Table.3 Rate of increase in G' values of unset/set AM during storage

\begin{tabular}{|l|c|c|c|}
\hline Sample & Temperature range & \multicolumn{2}{|c|}{$\begin{array}{c}\text { Rate of increase in } \\
\text { G' value }\end{array}$} \\
\hline Fresh & & Unset & Set \\
\hline Immediately frozen & $36.7^{\circ}-43.6^{\circ} \mathrm{C}$ & 5 times & 2.32 \\
\hline 30 days & $50.1^{\circ}-56.7^{\circ} \mathrm{C}$ & 5.75 times & 2.71 \\
\hline 90 days & $83.5^{\circ}-89.9^{\circ} \mathrm{C}$ & 3.26 times & 1.19 \\
\hline 120 days & $83.6^{\circ}-90.0^{\circ} \mathrm{C}$ & 5.89 times & 1.33 \\
\hline
\end{tabular}


Table.4 Comparative G' values at $50^{\circ} \mathrm{C}$ and $70^{\circ} \mathrm{C}$ of set and unset $\mathrm{AM}$ during storage

\begin{tabular}{|c|c|c|c|c|}
\hline \multirow{3}{*}{ Sample } & \multicolumn{4}{|c|}{ G' value dyne $/ \mathrm{cm}^{2} \times 1000$} \\
\hline & \multicolumn{2}{|c|}{$5^{\circ}{ }^{\circ} \mathrm{C}$} & \multicolumn{2}{|c|}{$\mathbf{7 0}^{\circ} \mathrm{C}$} \\
\hline & unset & set & unset & Set \\
\hline Fresh & 60.4 & 205.2 & 577.9 & 766.8 \\
\hline Immediately frozen & 19.8 & 137.0 & 364.1 & 943.3 \\
\hline 30 days & 4.8 & 444.8 & 10.3 & 854.8 \\
\hline 90 days & 4.5 & 27.2 & 7.7 & 309.7 \\
\hline 120 days & 12.0 & 24.0 & 40.6 & 227.9 \\
\hline
\end{tabular}

Table.5 Karl pearson's linear correlation co-efficients (r) between various physico-chemical and functional properties of $\mathrm{AM}$ stored at $-20^{\circ} \mathrm{C}$ for 150 days

\begin{tabular}{|l|l|l|l|l|}
\hline Parameters & $\begin{array}{l}\text { Storage } \\
\text { period }\end{array}$ & Extractability & $\begin{array}{l}\text { ATPase } \\
\text { activity }\end{array}$ & EC \\
\hline Extractability & $-0.9816^{\mathrm{a}}$ & & & \\
\hline ATPase activity & $-0.8317^{\mathrm{a}}$ & -0.3094 & & \\
\hline EC & $-0.969^{\mathrm{a}}$ & $0.9201^{\mathrm{a}}$ & 0.7043 & \\
\hline ES & $-0.983^{\mathrm{a}}$ & $0.954^{\mathrm{a}}$ & $0.8953^{\mathrm{a}}$ & $0.9455^{\mathrm{a}}$ \\
\hline WAC & $-0.7979^{\mathrm{a}}$ & $0.846^{\mathrm{a}}$ & $0.842^{\mathrm{a}}$ & $0.896^{\mathrm{a}}$ \\
\hline
\end{tabular}

$\mathrm{a}=\mathrm{P}<0.05$

The water absorption capacity of actomyosin as affected by freezing and frozen storage is given in Table 2. A reduction in WAC value was predominent due to freezing and values remained almost constant during frozen storage. In food system the amount of water bound by polar groups depends on their steric availability. Denaturation, a change in secondary/tertiary structure has little effect on the amount of water bound by proteins when expressed on a weight basis (Kinsella, 1982). In many system denaturation/aggregation which may actually decrease water binding by replacing water-protein interaction with protein - protein interaction (Hutton and Campbell 1981).

The surface active properties - EC and ES of actomyosin as a function of frozen storage decreased significantly (Fig.5). The process of freezing reduced the EC from 3.27 to $2.14 \mathrm{ml}$ of oil $/ \mathrm{mg}$ of protein. At the end of 150 days of storage the actomyosin lost its ability to emulsify the given quantity of oil. The emulsion capacity of protein from fish meat varies according to species and method of estimation (Swift et al., 1961). The freezing and frozen storage are known to affect emulsion capacity because of denaturation of major protein fractions. The role of DMA and formaldehyde in some gadoid species in cross linking the major protein fraction and reducing the emulsion capacity have been reported (Colmenero et al., 1988; Careche and Tejada 1990). The solubility of protein has a bearing on the emulsion capacity and bears direct relationship (Grabowska and sikorski 1974). In the present study the solubility of actomyosin had a significant effect on emulsion capacity during frozen storage $(r=0.9201, P<0.05)$. Similarly the emulsion stability values fell sharply on account of freezing to $7.2 \mathrm{~min}$ and decreased to $0.16 \mathrm{~min}$ at the end of 150 days of frozen 
storage (Fig. 5). The stability of an emulsion depends on various factors such as nature of interphase between oil and water, $\mathrm{pH}$, electrical charges and temperature (Dickinson and Stainsby 1982). It is not uncommon to find in some of the seed protein system where a denatured system exhibiting a higher ES (Aoki et al., 1980). In the present study the actomyosin of pinkperch lost the ES property because of changes in conformation as indicated by various physico-chemical properties like apparent reduced viscosity, solubility and ATPase enzyme activity.

The dynamic viscoelastic behaviour (DVB) in the range of $30^{\circ}-90^{\circ} \mathrm{C}$, of actomyosin stored at $-20^{\circ} \mathrm{C}$ for different period are depicted in Fig. 6. This small strain test was performed in order to elucidate the gelling process and to correlate with changes in other physicochemical and functional properties of actomyosin molecule. From the figure it can be seen that $G^{\prime}$ values which showed in the temperature range of $50-75^{\circ} \mathrm{C}$ decreased as a function of frozen storage period. The samples stored at 30,128 and 162 days, the $\mathrm{G}^{\prime}$ values didnot show any increase upto $75^{\circ} \mathrm{C}$ after which the values increased.

The temperature at which the rate of increase in $G^{\prime}$ values varied significantly with the age of actomyosin at $-20^{\circ} \mathrm{C}$ (Table 3). Also the possible reason for higher temperature for attaining maximum $G$ ' values could be due to the nature of interaction in actomyosin as affected by frozen storage. The hydrodynamic properties like viscosity, GF and solubility profile clearly demonstrated association/ dissociation phenomenon, which had a profound effect on gelling ability and process. The changes in $\tan \delta$ values (ratio of G'/G') of actomyosin as a function of frozen storage is given in Fig 7. Two transition temperature could be recorded in all the samples except the sample stored for 128 days, where only one transition at $50^{\circ} \mathrm{C}$ was recorded. The transition temperature varied from $36.7^{\circ} \mathrm{C}$ $70^{\circ} \mathrm{C}$. The two transition temperature could be related to development of elastic structure which is a two process step. Sano et al., (1988) observed that gelation of carp actomyosin occurred at temperature range of $30-41^{\circ} \mathrm{C}$ and $51-80^{\circ} \mathrm{C}$.

The setting ability of actomyosin was assessed at $30^{\circ} \mathrm{C}$ for $1 \mathrm{hr}$. The setting ability of actomyosin as a function of frozen storage period were evaluated. The gelation profile of actomyosin stored at $-20^{\circ} \mathrm{C}$ for different duration and set is represented in Fig 8. The set actomyosin had a higher elastic component compared to unset actomyosin at any given storage period. This can be substantiated by taking absolute $G^{\prime}$ values at 50 and $70^{\circ} \mathrm{C}$ at which temperature maximum structure build up takes place (Table 4), which clearly demonstrate the set actomyosin had a higher ability for building up elastic component. The ability to build up elastic structure of the set actomyosin decreased with increase in storage period. It is well understood that the involvement of hydrogen bonding, hydrophobic interaction and nondisulfide covalent linkage mediated by transglutaminase enzyme during setting of fishmeat (Kamath et al., 1992; Niwa, 1992; Lanier, 1986). The gelation profile of set actomyosin indicated two sol-gel transition temperatures as measured by $\tan \delta$ value (Fig. $9)$. The two sol-gel transition temperature for fresh set actomyosin were 43.5 and $83.3^{\circ} \mathrm{C}$. The change in sol-gel transition temperature of set actomyosin as a function of frozen storage did not alter significantly. However, only one transition at $50^{\circ} \mathrm{C}$ could be seen at the end of 120 days of storage. Sano et al., (1988) proposed that the first stage of elastic development was due to interaction among the tail portion of myosin molecule at 30$41^{\circ} \mathrm{C}$, and the second stage was attributed to hydrophobic interaction and disulfide bonds from head portion of myosin above $51^{\circ} \mathrm{C}$. 
From the study, it is evident that, the actomyosin from pinkperch contributed to functional and rheological properties significantly. The freezing and frozen storage of actomyosin altered the physico-chemical and functional properties significantly (Table 5) as indicated by hydrodynamic properties. The nature of interaction during frozen storage appears to be associative. Setting processes at $30^{\circ} \mathrm{C}$ for $1 \mathrm{hr}$ could enhance the gelling ability of actomyosin. The process of gelation revealed two transition temperatures viz. 36.7 and $63.3^{\circ} \mathrm{C} ; 43.5$ and $83.3^{\circ} \mathrm{C}$ for unset and set actomyosin respectively. The gelation process was altered by frozen storage. The association/dissociation had a bearing on surface active and hydration properties.

\section{Acknowledgement}

The authors express their thanks for the financial support by EEC. The authors wish to thank the Director of Instruction, College of Fisheries, UAS for presidios necessary facilities \& The Dean, FC\&RI, TANUVAS for necessary permission to pursue Ph.D. Programme.

\section{References}

An, H., Marshall, M.R., Otwell, W.S. and Wei, C.I. 1988. Electrophoretic identification of raw and cooked shrimp using various protein extraction systems. J. Food Sci., 53(2): 313-318.

An, H., Wei, C.I., Zhao, J., Marshall, M.R. and Lee, C.M. 1989. Electrophoretic identification of fish species used in surimi products. J Food Sci., 54(2): 253-257.

Aoki, H. Taneyama, O. and Orimo, N. 1980. Emulsifying properties of soy protein: Characteristics of $7 \mathrm{~S}$ and $11 \mathrm{~S}$ proteins. J. Food Sci. 45: 534-538.
Careche, M. and Tejada, M. 1990. The effect of neutral and oxidised lipids on the functionality in hake (Merluccius merluccius L.) a dimethyl amine and formaldehyde foaming species during frozen storage. Food chem., 36: 113128.

Chalmers, M., Careche, M. and Mackie, I.M. 1992. Properties of actomyosin isolated from cod (Gadus morhua) after various periods of storage in ice. J. Sci. Food Agric. 58: 375-383.

Colmenero, J.F., Tejada, M. and Borderias, A.I. 1988. Effect of seasonal variations in protein functional properties of fish during frozen storage. J. Food Biochem., 12: 159-170.

Connell, J.J. 1959. Aggregation of cod myosin during frozen storage. Nature, 183: 664-665.

Dickinson, E. and Stainsby, G. 1982. The oilwater interface and emulsion stability. In Colloids in food. p. 107-191. Applied science publishers, London.

Dyer, W.J. 1951. Protein denaturation in frozen stored fish. Food Res., 16: 522527.

Dyer, W.J. and Morton, M.L. 1956. Storage of frozen plaice fillets. J. Fish. Res. Board Can. 13: 129.

Fukuda, Y. 1986. Effect of freezing condition on quality of frozen fish meat. Refrigeration (Tokyo) 61: 18.

Grabowska, J.A. and Sikorski, Z. 1974. Proceedings IV Int. Congr. Food Sci. Technol., (Topic 2). CSIC, Madrid, Spain.

Hamann, D.D. 1992. Rheological studies of fish proteins. In international conference and Industrial exhibition on food hydrocolloids. Tsukuba, Japan, Nov, 16-20. pp. 4-49.

Hutton, C.W. and Campbell, A.M. 1981. Water and fat absorption In Protein Functionality in Foods, J.P. Cherry 
(ed.) pp. 177-198, ACS symposium series 147, ACS, washington, DC.

Ikeuchi, Y., Tanji, H., Kakimoto, T. and Suzuki, A. 1994. Dynamic rheological behaviour and biochemical properties of rabbit skeletal actomyosin during storage at $0^{\circ}$ C. J. Sci. Food Agric., 65: 77-84.

Ishioroshi, M., Samejima, K. and Yasui, T. 1979. Heat-induced gelation of myosin factors of $\mathrm{pH}$ and salt concentration. $\mathrm{J}$. Food Sci. 44: 1280.

Jiang, S.T. 1977. Studies on the denaturation of mullet musscle protein during frozen storage. Refrigeration (Tokyo) 52: 621 .

Jiang, S.T., Hwang, D.C. and Chen, C.S. 1988a. Denaturation and change in $\mathrm{SH}$ group of actomyosin from milk fish during frozen storage at $-20^{\circ} \mathrm{C}$. J. Agric. Food Chem., 36: 433-437.

Jiang, S.T., Hwang, D.C. and Chen, C.S. 1988b. Effect of storage temperatures on the formation of disulfides and denaturation of milk fish actomyosin (Chanos chanos) J. Food Sci., 53: 13331335.

Kamath, G.G., Lanier, T.C., Foegeding and Hamann, D.D. 1992. Non-disulphide covalent crosslinking of myosin heavy chain in setting of Alaska pollack and Atlantic croaker surimi. J. Food Biochem., 16: 151.

Kawashima, M., Aral, K. and Satto, T. 1973. Studies on muscular proteins of fish IX. An attempt on quantitative determination of actomyosin in frozen 'surimi' from Alaska pollack. Bull. Jap. Soc. Fish., 39: 207-214.

Kinsella, J.E. 1982. Relation between structural and functional properties of food protein. In: Food proteins, R.F.Fox, and J.J. Condon, (eds.). pp. 51-103, Applied science publishers, New York.

Kinsella, J.E., Rector, D.J. and Philips, L.G. 1994. Physio chemical properties of proteins: Texturization via gelation glass and film formation. In protein structure - function relationships in foods, R.Y. Vada, R.L. Jackman, and J.L. Smith, (eds.). pp. 20. Blackie Academic and Professional, London.

Lanier, T.C. 1986. Functional properties of surimi. Food Technol. 107.

Lanier, T.C., Lin, T.S., Liu, Y.M. and Hamann, D.D. 1982. Heat gelation properties of actomyosin and surimi prepared from atlantic croaker. J. Food Sci., 47: 1921.

Lin, T.M. and Park, J.W. 1998. Solubility of salmon myosin as affected by conformational changes at various ionic strengths and pH. J. Food Sci., 63: 215218.

Matsumoto, J.J. 1980. Chemical deterioration of muscle protein during frozen storage. In Chemical Deterioration of Protein, J.R. Whitaker and M. Fugimaki, (eds.). pp. 95-124. ACS Symposium series 123, ACS, Washington, DC.

Montecchia, C.L., Roura, S.I., Roladan, H., Perejborla, O. and Crupkin, M. 1997. Biochemical and physico-chemical properties of actomyosin from frozen pre-and post-spawned hake. J. Food Sci., 62: 491-495.

Niwa, E. 1992. Chemistry of surimi gelation. In: Surimi Technology T.C. Lanier and C.M. Lee, (eds.). p. 389, Mercel Dekker, Inc., New York.

Noguchi, S. and Matsumoto, J.J. 1978. Modification of thermal and nonthermal gelation of carp actomyosin by additive compounds. Bull. Jap. Soc. Sci. Fish. 44: 273-278.

Noguchi, S.F. 1986. Dynamic viscoelastic changes of surimi (minced fish meat) during thermal gelation. Bull. Jap. Soc. Sci. Fish. 52: 1261-1270.

Rathnakumar, K. and Shamasundar, B.A. 2004a. Physico-chemical, functional and rheological properties of proteins 
from pinkperch (Nemipterus japonicus) meat: Effect of freezing and frozen storage.

Samejima, K., Ishioroshi, M. and Yasui, T. 1981. Relative roles of the head and tail poritions of the molecule in heat induced gelation of myosin. J. Food Sci., 46: 1412.

Sano, T., Noguchi, S.F., Tsachiya, T. and Matsumoto, J.J. 1988. Dynamic visco elastic behaviour of natural actomyosin and myosin during thermal gelation. J. Food Sci., 53: 9224.

Sano, T., Ohno, T., Fuchino, H.O. Matsumoto, J.J. and Tsuchiya, T. 1994. Carp natural actomyosin: Thermal denaturation mechanism. J. Food Sci. 59: 1002-1008.

Shamasundar, B.A. and Prakash, V. 1994a. Physico-chemical and functional properties of proteins from prawn (metapenaeus dobsoni). J. Agric. Food Chem., 42: 169-174.

Shenouda, S.Y.K. 1980. Theories of protein denaturation during frozen storage of fish flesh. Adv. Food Res., 26: 275-311.

Swift, C.E., Lockett, C. and Fryer, A.J. 1961. Communated meat emissions the capacity of meats for emulsifying fat. Food Technol., 15: 468.

Tejada, M. 1994. Gelation of myofibrillar fish proteins. Rev. Esp. Cienc. Technol. Aliment. 34, 257-273.

Wagner, J.R and Anon, M.C. 1986. Effect of frozen storage on protein denaturation in bovine muscle. 1. Myofibrillar ATPase activity and differential scanning calorimetric studies. J. Food Technol. 21: 9-14.

Wu, M.C., Lanier, T.C. and Hamann, D.D. 1985a. Thermal transitions of actomyosin and surimi prepared from Atlantic Croaker as studied by differential scanning calorimetry. J. Food Sci., 50: 10-13.

Wu, M.C., Lanier, T.C. and Hamann, D.D. 1985b. Rigidity and viscosity changes of croaker actomyosin during thermal gelation. J. Food Sci., 50: 14-19.

Xiong, L.Y. 1997. Structure function relationships of muscle proteins. In Food proteins and their applications, S. Damodaran, and A. Paraf, (eds.). pp. 341-386, Marcel Dekker. Inc. New York.

\section{How to cite this article:}

Rathnakumar K. and Shamasundar B. A. 2018. Effect of Freezing and Frozen Storage on the Properties of Actomyosin from Pinkperch (Nemipterus japonicus). Int.J.Curr.Microbiol.App.Sci. 7(06): 3096-3112. doi: https://doi.org/10.20546/ijcmas.2018.706.364 